\title{
Evaluation of Some New Navel Orange Cultivars Budded on Sour Orange and Volkamer Lemon Rootstocks
}

\author{
M.A. Nasser, A.Z. Bondok, A.D. Shaltout and Noha Mansour \\ Department of Horticulture, Faculty of Agriculture, Ain Shams \\ University, Cairo, Egypt.
}

\begin{abstract}
FIELD EXPERIMENT was carried out in a private orchard at Wady El-Mollak, El-Sharqia Governorate, Egypt during two successive seasons (2012 and 2013) to evaluate flowering, fruit set, fruit drop, yield, fruit quality, mineral and total carbohydrates content of some newly introduced Navel orange cultivars (New Hall, Navelina, Navelate, Lane Late, Cara Cara, Spring, Fisher, Parent, Fukumoto and Leng). These cultivars were grafted on two commercial rootstocks "Sour orange" (Citrus aurantium L.) and "Volkamer lemon" (Citrus Volkameriana L.). The present experiment comprises ten scions and two rootstocks. The experiment was laid out in factorial experiment in a randomized complete block design.
\end{abstract}

Results showed that, the effect of cultivars namely, Navelate, Lane Late, New Hall and Navelina gave the highest values of fruit set and the lowest values of fruit drop. Whereas, New Hall gave the highest values of fruit weight and yield/tree followed by Navelina and Lane Late but New Hall gave large fruit size which not accepted in export and local market. Meanwhile, New Hall and Navelina cultivars gave the highest values of TSS, TSS/acid ratio and the lowest values of acidity. On the other hand, "Cara Cara" "Spring" and "Leng" gave significant lower values of $\mathrm{N}$ content than other Navel orange cultivar. Navelate and Lane Late gave the highest values of $\mathrm{P}, \mathrm{K}$ and $\mathrm{Ca}$. Regarding the effect of rootstocks, Volkamer Lemon rootstock gave the significant highest values of flowering, fruit set, fruit drop, yield parameters, peel thickness, macro and micronutrients content (N, P, K, $\mathrm{Ca}, \mathrm{Mg}, \mathrm{Fe}, \mathrm{Zn}$, and $\mathrm{Mn}$ ) as compared with sour orange rootstock. On the other hand, Sour orange gave the significant highest values of juice volume, TSS, TSS/acid ratio. Volkamer Lemon gave lower values of total carbohydrates consequently gave lower values of $\mathrm{C} / \mathrm{N}$ ratio than Sour orange rootstock. Regarding the combination between cultivars and rootstocks, Lane Late and New Hall cultivars on Volkamer Lemon gave the highest values of flowering, fruit set percentages and lower values of fruit drop as compared with other combinations. New Hall budded on both rootstocks gave the highest values of yield followed by Lane Late on Volkamer Lemon. The highest values of TSS, TSS/acid ratio were obtained when New Hall and Navelina budded on sour orange followed closely by the same cultivars on Volkamer Lemon rootstock and the trend was reversed for acidity. The highest values of $\mathrm{N}, \mathrm{P}, \mathrm{Ca}, \mathrm{Mg}, \mathrm{Fe}$ and $\mathrm{Mn}$ were obtained 
when Lane Late budded on Volkamer Lemon rootstock. All Navel orange cultivars budded on Volkamer Lemon rootstock gave lower $\mathrm{C} / \mathrm{N}$ ratio than budded on Sour orange rootstock. In spite of Volkamer Lemon rootstock gave higher values of yield/tree than sour orange but with low fruit quality especially for peel thickness, TSS and TSS/acid ratio. Finally it could be concluded that, New Hall gave the highest values of fruit weight and yield/tree followed by Navelina and Lane Late but New Hall especially on Volkamer Lemon gave large fruit size which not accepted in export and local market. So, it could be recommended by budded Navelina and Lane Late cultivars on Sour orange rootstock for suitable yield with high fruit quality.

Keywords: Fruit quality- Mineral content- Newly Navel orange cultivarsSour orange- Volkamer Lemon- Yield.

Citrus harvested areas increased rapidly from year to year and reached about 439024 fedden in 2013 which produced an average of 9.5 tons/fedden. Oranges are the most extensively produced citrus fruit which reached about 2,855,022 tons represented about 69.66\% (Agricultural Statistics Institute, 2013). Extension of the cultivated area is due to fit environmental conditions, has a great attention due to its importance for local consumption, it highly economic value as a main source for exportation to the European countries and Gulf States Barakat et al. (2012). Egyptian exports are mainly from oranges (Navel and Valencia) which comprise the vast majority of citrus exports. The volume of Egyptian exports of orange reached about 1.102 .538 ton representing $38.6 \%$ of the total production (UPECH, 2013). Generally, Egypt has excellent opportunities for expanding its exports due to its favorable climate and strategic geographic location.

It is evident that virus and virus-like diseases are limiting yields in Egyptian citrus orchards, perhaps by as much as 10 or $20 \%$ overall and much more severely in certain orchards. The use of disease-free bud wood for new plantings helps to prevent or minimize diseases damage that have insect vectors (FAO Corporate document Repository). Citrus trees are not native to the Mediterranean basin, they were introduced from their origins in Southeast Asia and the Malayan archipelago. It is well known that in all important citrus-producing areas of the world there is a constant interest in new and better varieties and stocks of the genus Citrus, and that a more or less continuous flow of plant introductions is occurring everywhere. Egyptian government agencies and private sectors import new, desirable varieties and use modern laboratory techniques to preclude diseases and pests, through the project of (Egyptian - German citrus improvement program) in Bahtim Res. station.

Navel orange is considered the most popular citrus fruits for Egyptians. Washington navel orange is often called parent navel orange, is the best known navel orange and is often used as standard for the industry (Ferguson et al., 2014). Many other navel orange cultivars like (New Hall, Navelina, Navelate, Lane Late, Cara Cara, Spring, Fisher, Fukumoto and Leng) were imported and are now important to the citrus industry because they mature at slightly different

Egypt. J. Hort. Vol. 41, No. 2 (2014) 
times (extending the season from fall through summer) were sport selection of Washington navel orange.

In the Mediterranean region, all citrus cultivars are mainly budded on sour orange (Citrus aurantium L.), due to its resistance to gummosis fungi, high adaptability to wide range of soil conditions and the ability to produce high fruit quality. However, Sour orange has shown to have some serious problems such as susceptibility to the citrus Tristeza virus and poor compatibility with some citrus cultivars (Castle, 2010).

According to the fact that, sour orange is susceptible to viral diseases such as "Tristeza" several rootstocks were introduced and tested for their compatibility, tolerance and adaptability to avoid the risk of future incidence in Egypt citrus orchards. Volkamer lemon is the second common rootstocks in Egypt especially in the newly reclaimed soils (Hudson et al., 1990).

Volkamer lemon (Citrus Volkameriana L.) is a lemon hybrid and produces the most tree vigorous growth for the scions. Volkamer lemon appears to be one of the most promising rootstocks because its tolerance to Tristeza (Shafieizargar et al., 2012).

Therefore, the present study was conducted with an objective to evaluate flowering, the fruit set, fruit drop, yield, fruit quality, mineral and total carbohydrates content of some newly introduced Navel orange cultivars grafted on two commercial rootstocks "Sour orange and Volkamer lemon" in Egypt

\section{Materials and Methods}

A field experiment was carried out in a private orchard at Wady El-Mollak, El-Sharqia Governorate, Egypt during two successive seasons (2012 and 2013) on some newly introduced Navel orange cultivars "New Hall, Navelina, Navelate, Lane Late, Cara Cara, Spring, Fisher, Parent, Fukumoto and Leng" budded on two citrus rootstocks Sour Orange (Citrus aurantium L) (SO) and Volkamer lemon (Citrus Volkameriana L.) (VL). Thus, the present experiment comprises ten scions and two rootstocks. So, the experiment was laid out in factorial experiment in a randomized complete block design with five replicates and each replicate was represented by one tree. The orange trees were selected on the basis of similarity in age "about seven years old", normal growth vigor, healthy, their flowering \& fruiting behaviors. All trees received the same cultural practices and planted at $4 \times 6$ meter apart in sandy soil under drip irrigation system. Soil samples were taken from three locations of the experimental area at $0-30,30-60$ and $60-90 \mathrm{~cm}$ from the soil surface for physical and chemical analysis, which carried out according to Jackson (1958), Black et al. (1965) and Wilde et al. (1979) were shown in Table 1 and 2. 
TABLE 1. Physical properties of the experimental soil

\begin{tabular}{|l|c|c|c|c|c|}
\hline \multirow{2}{*}{$\begin{array}{l}\text { Organic } \\
\text { matter }\end{array}$} & \multicolumn{5}{|c|}{ Particle size distribution } \\
\cline { 2 - 6 } & Sand (\%) & Silt (\%) & Clay (\%) & Soil Texture & Field capacity (\%) \\
\hline 0.02 & 90.66 & 8.633 & 0.703 & Sand & 20.2 \\
\hline
\end{tabular}

TABLE 2. Chemical properties of the experimental soil

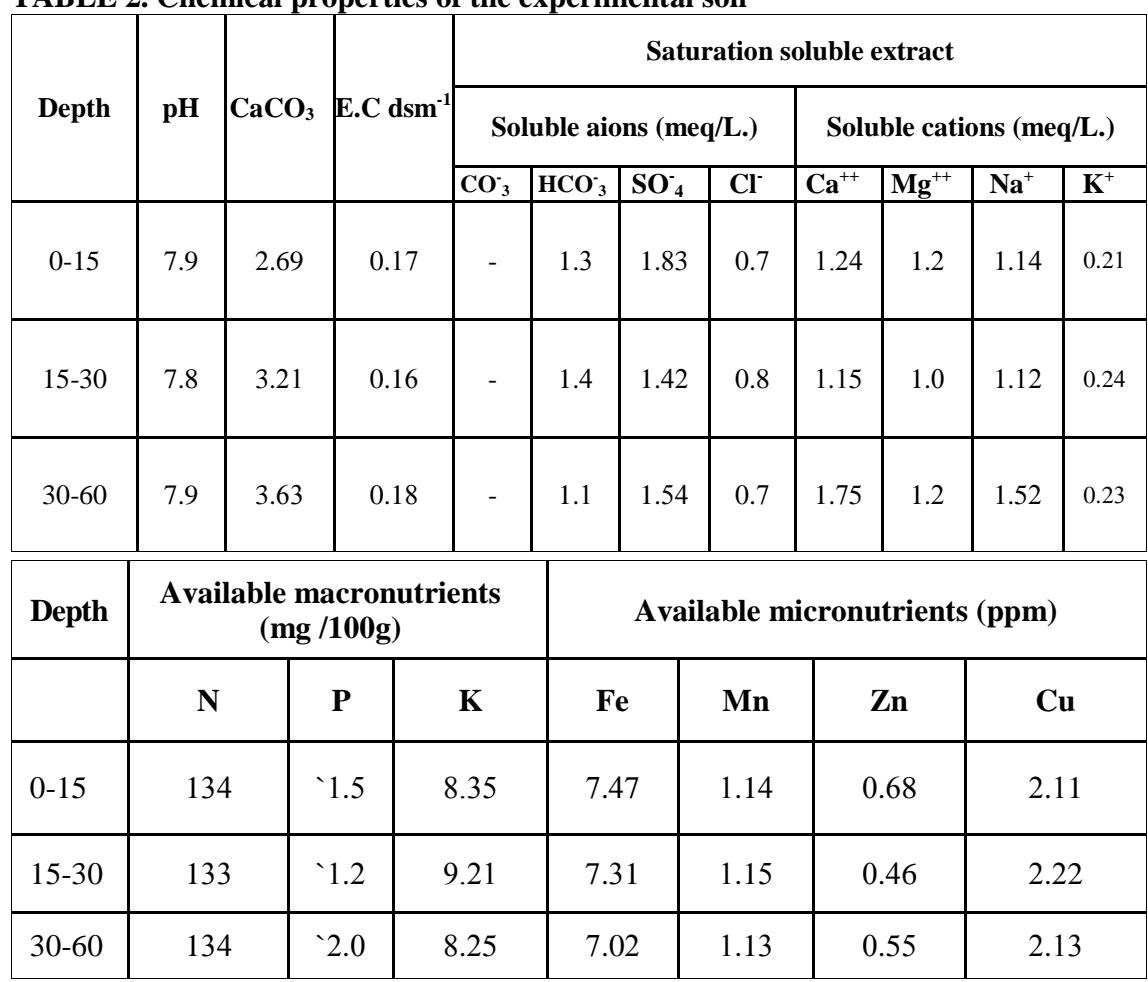

The effect of the aforementioned treatments on fruit set, yield, fruit quality, mineral and total carbohydrates content in the two studied seasons were investigated as follows

The percentage of bud flowering, fruit set and fruit drop

Flowering bud $\%=$ (number of flowers bud /total number of buds) $\times 100$

Number of flowers at full bloom was counted for both leafy and woody inflorescences to determine the fruit set. Fruits were counted after two weeks of full bloom and fruit setting was calculated by using the following formula: Fruit set $(\%)=$ [Total number of fruitlets/ Total number of flowers $] \times 100$ Fruit drop $(\%)=[($ Total no. of fruitlets - No. of fruits in late Jun $) /$ Total no. of fruit lets] x 100 
Yield

At maturity, the average number of fruits/ tree was counted on the mid of December of each season. Moreover, 10 fruits from each tree (replicate) were weighted, then the tree yield was theoretically calculated $(\mathrm{kg})$.

\section{Fruit quality}

For each season, sample of five fruit / tree was randomly selected and used for the determination of the following physical and chemical properties:

Fruit shape, fruit firmness, peels thickness $(\mathrm{mm})$ and juice volume $\left(\mathrm{ml}^{3}\right)$. The ascorbic acid content was determined by using 2, 6 dichlorophenolindophenol dye and 3\% oxalic acid as substrate. Ascorbic acid was calculated as mg per 100 $\mathrm{ml}$ of juice. The titratable acidity was determined by titrating five $\mathrm{ml}$ of juice against sodium hydroxide $(0.1 \mathrm{~N})$ using phenolphthalein indicator. The acidity percentage was calculated as $\mathrm{mg}$ anhydrous citric acid per $100 \mathrm{ml}$ of juice according to the A.O.A.C. (1995). The total soluble solids (TSS) were determined as \% in juice by means of hand refractometer. The TSS/ Acid ratio was calculated.

\section{Chemical analysis}

Leaf mineral content was determined as follows: twenty leaves nearly of 5-7 months age were randomly collected from each replicate. The leaf samples were washed several times with tap water then rinsed with distilled water, dried at $70^{\circ} \mathrm{C}$ in an electric oven till a constant weight. Dry leaves were grounded and digested using sulphoric acid and oxygen peroxide according to (Jackson, 1973). Leaf mineral content of $\mathrm{N}, \mathrm{P}, \mathrm{K}, \mathrm{Ca}, \mathrm{Mg}, \mathrm{Fe}, \mathrm{Zn}$ and $\mathrm{Mn}$ were determined on dry weight. according to (Cottenie et al., 1982).

\section{Total carbohydrates content}

Total carbohydrates content was estimated in stems at the first week of October in each season using the phenol sulfuric method according to Dubois et al. (1956) after the hydrolysis of carbohydrates, $\mathrm{C} / \mathrm{N}$ ratio was calculated as follows: $\mathrm{C} / \mathrm{N}$ ratio $=$ Total carbohydrates of stem/ total nitrogen of stem.

\section{Statistical analysis}

The data of the experiment were subjected to proper statistical analysis of variance according to Snedecor and Cochran (1980). Duncan test was used to compare between means. Data were statistically analyzed using the analysis of variance adopting a SAS package.

\section{Results and Discussion}

\section{The percentage of flowering, fruit set and fruit drop}

Result in Table 3 show the effect of some newly Navel orange cultivars on two rootstocks on the percentage of flowering, fruit set and fruit drop during 2012 and 2013 seasons. In the two seasons, the percentage of flowering, fruit set and fruit drop were significantly affected by Navel orange cultivars, rootstocks and their interaction. Consequently, the highest significant values of flowering percentage were obtained by Lane Late cultivar followed closely by Parent, 
Spring and Fisher especially in the second season. On the other hand, VL rootstock gave the highest significant values as compared with SO. Regarding the interaction, the highest significant values were obtained by Lane Late and Parent on VL rootstock followed closely by Fisher on VL and Lane Late on SO especially in the first season.

Concerning the percentage of fruit set, the lowest significant values were obtained by Cara Cara cultivar in the two studied seasons. While, the highest significant values were obtained by Navelate followed closely by Lane Late, New Hall, Navelina and Leng, respectively especially in the first season. On the other hand, VL rootstock gave the significant highest values as compared with SO. Regarding the interaction, the highest significant values were obtained when all cultivars budded on VL rootstock as compared with SO.

Concerning the percentage of fruit drop, the lowest significant values were obtained by Navelina, Lane Late, New Hall and Navelate cultivars. On the other hand, the lowest significant values were obtained by SO rootstock in the two seasons. Regarding the interaction, the lowest values were obtained when New Hall and Navelina budded on SO in the two growing season.

From the foregoing results, it could be concluded that, generally Navelate, Lane Late, New Hall and Navelina cultivars gave the highest values of fruit set and the lowest values of fruit drop. On the other hand, for all characters VL rootstock gave the highest significant values as compared with SO. Regarding the combination between Navel orange cultivars and two rootstocks in most cases, it is clear that Lane Late and New Hall cultivars on VL gave the highest values of flowering, fruit set percentages and lower values of fruit drop as compared with the other combinations

The obtained results are in agreement with those reported by Zayan et al. (2004) that the highest significant values for the percentage of bud flowering, fruit set and fruit drop were obtained by VL as compared with SO.

\section{Yield}

Data in Table 4 show the effect of some Navel orange cultivars on two rootstocks on fruit number, fruit weight and tree yield during 2012 and 2013 seasons.

Values of fruit number, fruit weight and yield were significant affected by Navel orange cultivars, rootstocks and their interaction in the two seasons.

Consequently, the significant highest values of fruit number were obtained by Navelate and Cara Cara especially in the second season. Regarding rootstocks, in the first season VL gave the significant highest values for fruit number but in the second season it was not significant between them. Regarding the interaction it was clear that Navelate and Cara Cara budded on both rootstocks gave the significant highest values in the two seasons.

Egypt. J. Hort. Vol. 41, No. 2 (2014) 
EVALUATION OF SOME NEW NAVEL ORANGE CULTIVARS ...

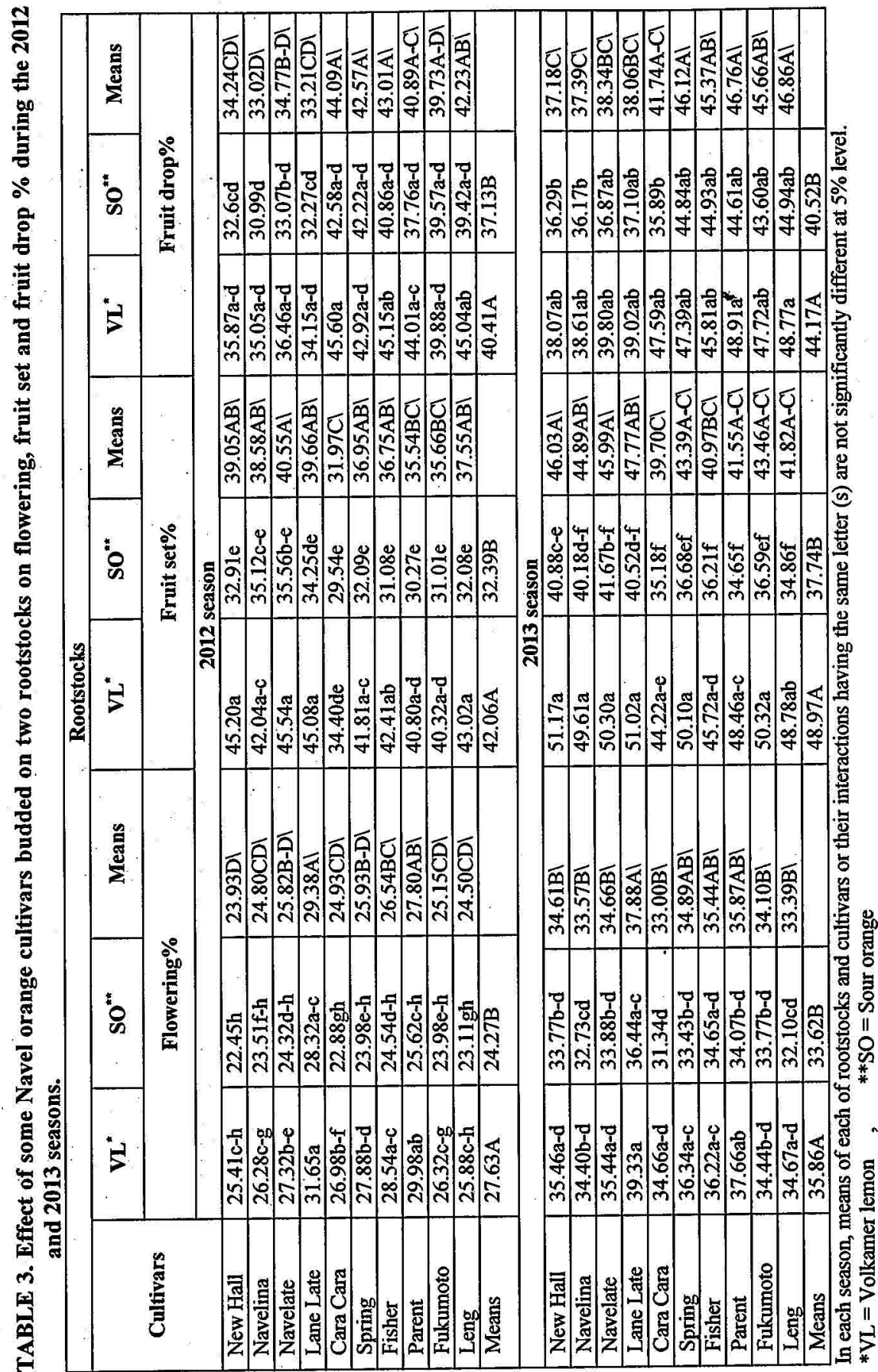

Egypt. J. Hort. Vol. 41, No. 2 (2014) 


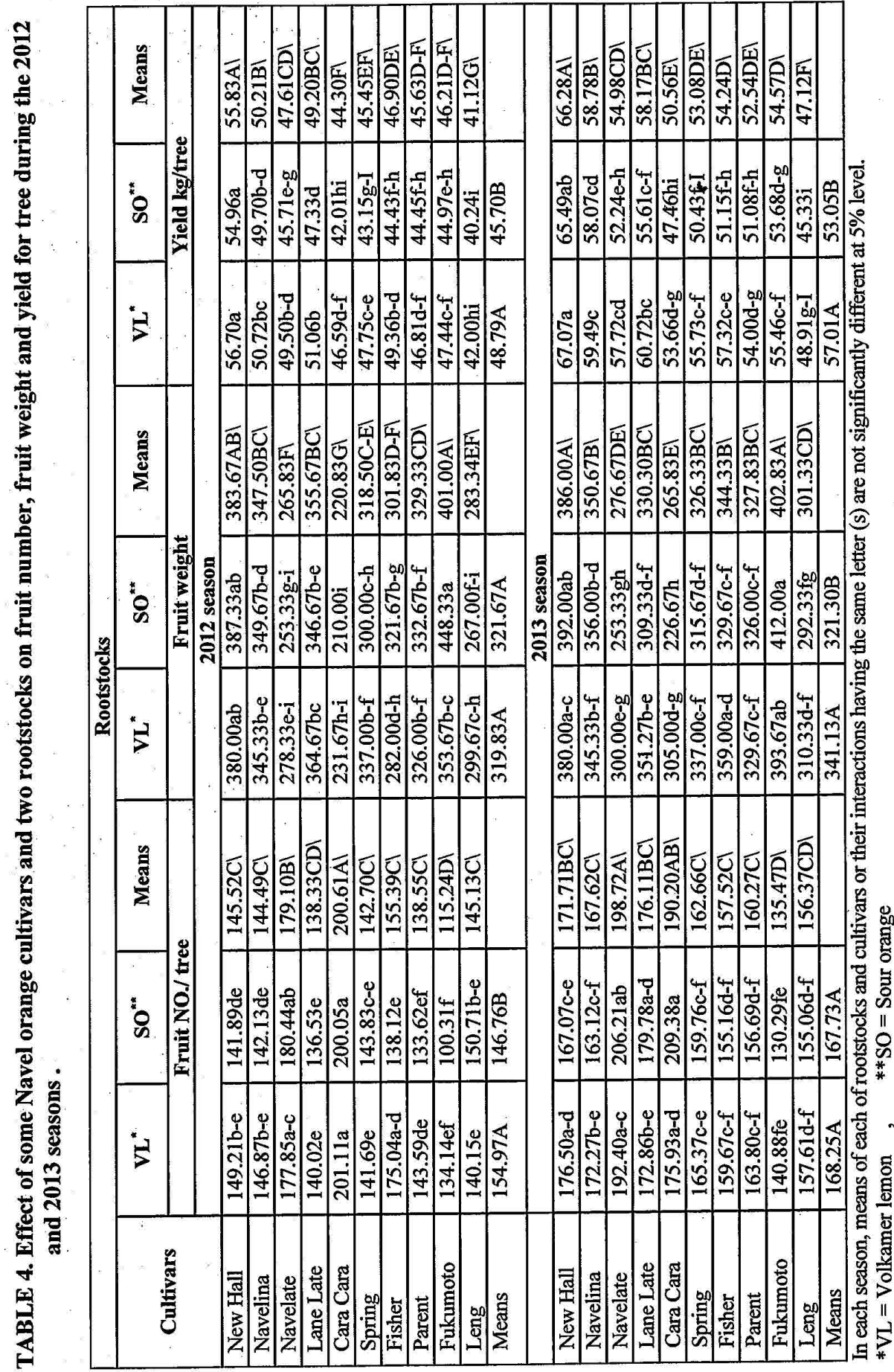

Egypt. J. Hort. Vol. 41, No. 2 (2014) 
The significant highest values of fruit weight were obtained by New Hall and Fukumoto followed by Lane Late and Navelina especially in the first season. Regarding rootstocks, in the first season, it's effect was not significant for fruit weight but in the second season VL gave the significant highest values of fruit weight. Regarding the interaction it was clear that New Hall and Fukumoto budded on both rootstocks gave the significant highest values of fruit weight in the two seasons except Fukumoto budded on VL in the first season.

Concerning yield, results proved that the highest significant values were obtained by New Hall followed by Navelina and Lane Late cultivars. Regarding rootstocks, significant the highest values obtained by VL rootstock in the two seasons. The significant highest values of the interaction were obtained when New Hall budded on both rootstocks followed by Lane Late on VL.

From the above results, it could be concluded that New Hall gave the highest values of fruit weight and yield per tree followed by Navelina and Lane Late. In most cases, it is clear that yield parameters were increased when budded on VL as compared with SO rootstock. Regarding the interaction between cultivars and rootstocks, it is observed that, the highest values were obtained when New Hall budded on both rootstocks

The obtained data are in harmony with those reported by Ibrahim et al. (2004), Shafieizargar et al. (2012) and Barakat et al. (2013) on Navel and Valencia oranges cultivars. They reported that VL rootstock induced higher values of fruit weight and yield as compared with SO rootstock.

Fruit quality

Fruit physical properties

Result in Table 5 and Fig. 1 show the effect of some newly Navel orange cultivars budded on two rootstocks on fruit physical properties during 2012 and 2013 seasons.

In the two seasons, values of fruit shape, fruit firmness, peel thickness and juice volume were affected significantly by Navel orange cultivars, rootstocks and their interaction.

Consequently, the significant highest values of fruit shape were obtained by New Hall and Fukumoto cultivars especially in the second season while, fruit shape was not affected significantly by rootstocks in both seasons. With respect to combination between cultivars and rootstocks it is observed that, the effect varied slightly from season to another and the trend was clearer in the first season than the second whereas, the significant highest values were obtained by New Hall, Parent, Fukumoto and Leng on each rootstocks, other combinations gave more or significant less lower values expect Spring on SO. In the second season, the significant lowest value was obtained by Parent on VL. 


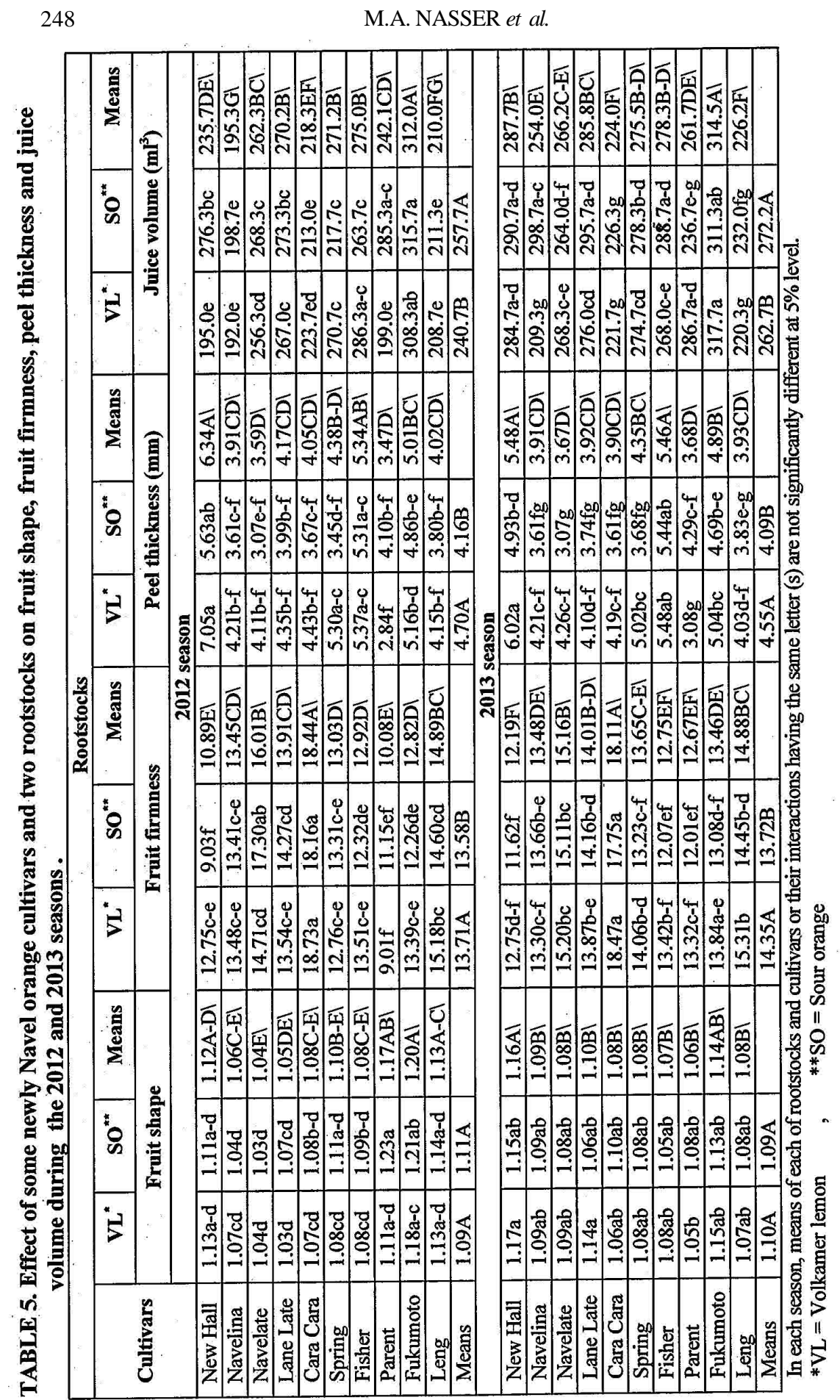

Egypt. J. Hort. Vol. 41, No. 2 (2014) 

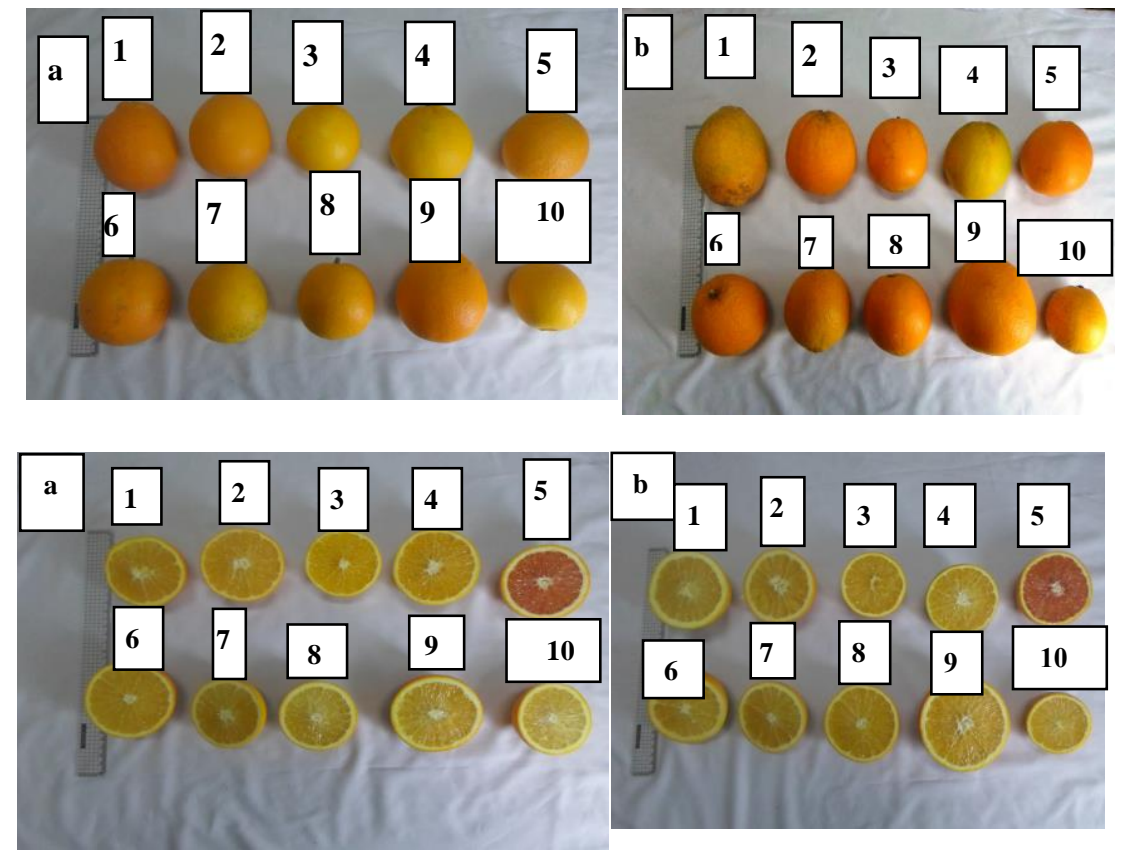

Fig. 1. Some newly Navel orange cultivars budded on sour orange and Volkamer Lemon rootstocks (a) Cultivars budded on sour orange (b) Cultivars budded on Volkamer lemon (1)New Hall (2) Navelina (3) Navelate (4) Lane Late (5) Cara Cara (6) Spring (7) Fisher (8) Parent (9) Fukumoto (10) Leng

Data concerning fruit firmness indicated that, the highest fruit firmness values were obtained by Cara Cara cultivar followed by Navelate in the two growing seasons. Regarding the effect of rootstock, it is observed that, VL gave the significant higher values than $\mathrm{SO}$ in the two growing seasons. Results revealed that Cara Cara gave the highest significant values in each rootstock and other combinations gave significantly lower values except Navelate on SO and Fukumoto on VL in the first and second seasons, respectively.

The significant highest values of peel thickness were obtained by New Hall cultivar followed closely by fisher cultivar during the two seasons. On the other hand, in the two seasons, VL gave significant higher values than SO rootstock. Generally, the significant highest values were obtained by New Hall on VL and Fisher on each rootstock in both seasons. Other combinations gave more or less significantly lower values except New Hall on SO and Spring on VL in the first season.

The significant highest values of juice volume were obtained by Fukumoto cultivar during two seasons. Regarding the effect of rootstocks it is noticed that, SO gave the significant highest values in the two seasons. The interaction was 
significant in the two seasons whereas the effect varied from season to another. In the first season, the significant highest values were obtained by Fukumoto on each rootstock, Fisher on VL and Parent on SO. On the other hand, many other different combinations gave the significant highest values in the second season such as (New Hall and Fukumoto) on each rootstock, (Navelina, Lane Late and Fisher) on SO and Parent on VL.

From the foregoing results, it is noticed that New Hall cultivar especially on VL rootstock gave the highest values of fruit weight and yield per tree but with large fruit size and high values of peel thickness which not accepted in export and local market. (Personal communication with Elwadi Export for Agricultural Products)

In this respect, Zayan et al. (2004) on Valencia orange and Shafieizargar et al. (2012) on 'Queen' orange pointed out that, trees grafted on VL produced the largest fruits as compared with SO. Also, Ibrahim et al. (2004) reported that the significant highest values of peel thickness were obtained by Volkamer lemon whereas sour orange gave lowest values of peel thickness.

\section{Fruit chemical properties}

Data in Table 6 show the effect of different Navel orange cultivars, rootstocks and their interaction on vitamin C, TSS\%, acidity and TSS/acid ratio during 2012 and 2013 seasons. Results showed that values of such parameters were significantly affected by Navel orange cultivars, rootstocks and their interaction through the two seasons.

Consequently, the significant highest values of vitamin $\mathrm{C}$ were obtained by New Hall cultivar during two seasons. Regarding the effect of rootstocks it is noticed that, SO gave the significant highest values in the two seasons. Regarding the interaction, the significant highest values were obtained by New Hall budded on each rootstocks and Spring budded on VL.

Concerning TSS, results proved that New Hall, Navelina and Leng cultivars gave the significant highest values. Regarding the rootstock, the significant highest values were obtained by VL rootstock in the two seasons. Regarding the interaction, the significant highest values of TSS were obtained when (New Hall, Navelina, Fisher, Fukumoto and Leng) were budded on each rootstock and Spring was budded on SO through two seasons.

Acidity was not affected significantly by Navel orange cultivars, rootstocks and their interaction in the two seasons except the effect of rootstocks in the second season whereas, rootstock gave the significant highest values of acidity. Navel orange cultivars had no effect on juice acidity. So, the results of both seasons clearly indicated that juice acidity was more or less similar for all combinations. 
EVALUATION OF SOME NEW NAVEL ORANGE CULTIVARS ...

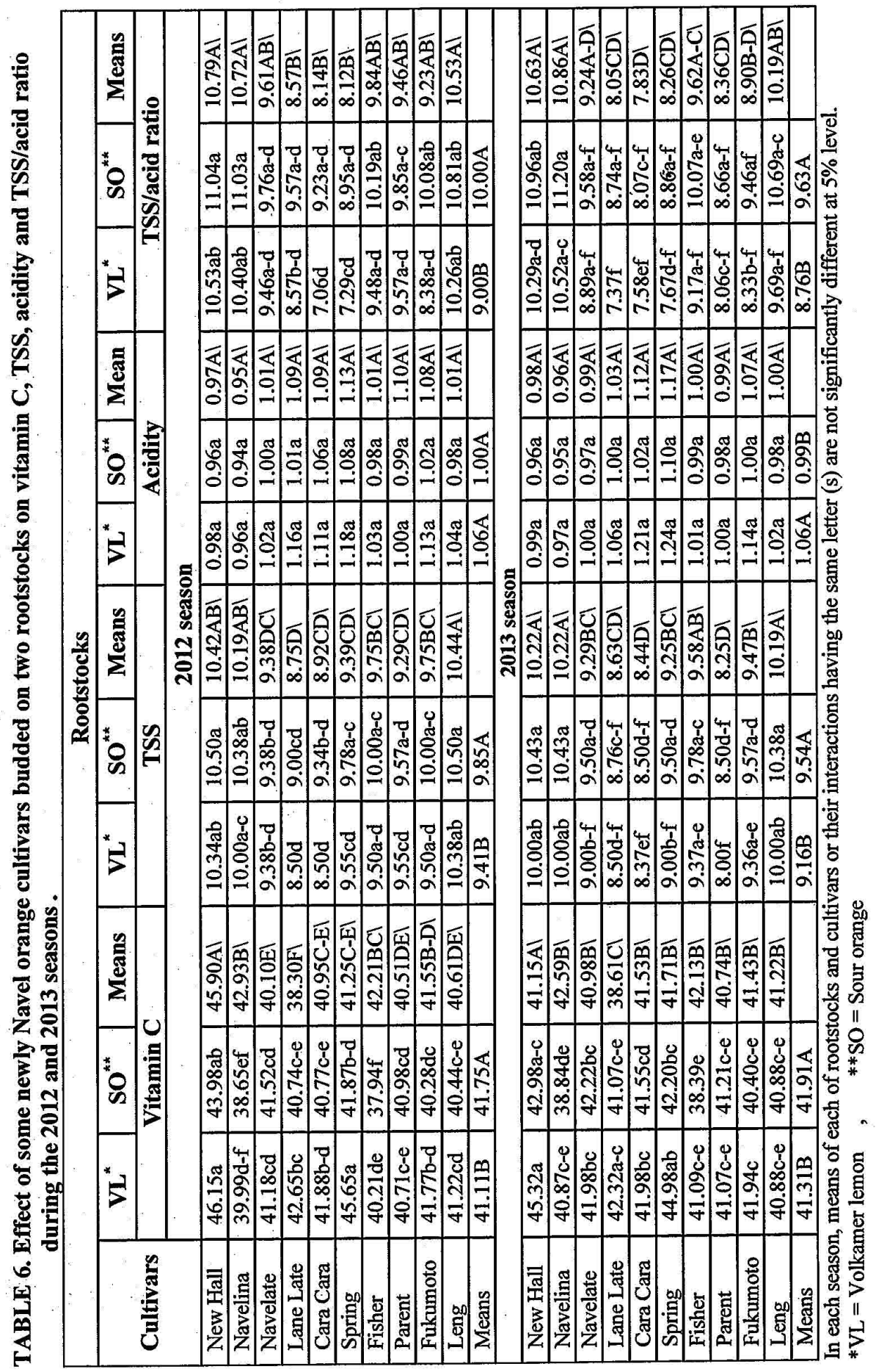

Egypt. J. Hort. Vol. 41, No. 2 (2014) 
Regarding TSS/acid ratio, results showed that the significant highest values were obtained by many different cultivars such as (New Hall, Navelina, Navelate, Fisher and Leng in the two growing seasons. With respect to rootstocks it was observed that, SO rootstock gave the significant highest values of TSS/acid ratio in the two seasons. Regarding the interaction it was clear that the trend was slightly different from one season to another. In the first season, the significant lowest values were obtained from Lane Late, Cara Cara and Spring budded on VL. On the other hand, in the second season, the significant lowest values were obtained when budded Cara Cara on each rootstock and (Lane Late, Spring, Parent and Fukumoto) on VL rootstock. Other combinations gave more or less similar high values with the same statistical standpoint.

From the foregoing results, it is noticed that New Hall cultivar gave the highest values of vitamin C. Regarding other fruit chemical properties, New Hall and Navelina cultivars gave the highest values of TSS and TSS/acid ratio and the lowest values of acidity. On the other hand, SO gave the significant highest values of all fruit chemical properties except acidity whereas gave the lowest values. Regarding the interaction between cultivars and rootstocks, it is observed that, the highest values were obtained when New Hall and Navelina budded on SO followed closely by the same cultivars on VL rootstock and the trend was reversed for acidity.

Finally it could be concluded that, In spite of Volkamer lemon rootstock gave higher values of yield/tree than sour orange but with low fruit quality especially for peel thickness, TSS and TSS/acid ratio.

In this respect, Fruit from trees on SO tended to have higher ascorbic acid content than fruits from many other rootstocks. Fruits on SO rootstock are smooth, thin skinned, juicy, excellent in quality, and hold up well without appreciable deterioration after maturity (Harding et al. 1940). Hifny et al. (2012) pointed out that, Washington Navel orange fruits from trees budded on SO had higher vitamin C content and TSS \% as compared with fruits from trees on VL.

\section{Chemical analysis \\ Effect on leaf macronutrients content \\ Results in Table 7 show the effect of different Navel orange cultivars, rootstocks and their interaction on $\mathrm{N}, \mathrm{P}, \mathrm{K}, \mathrm{Ca}$ and $\mathrm{Mg}$ content in leaves of Navel orange trees in 2012 and 2013seasons. In the two seasons, macronutrients (N, P, $\mathrm{K}, \mathrm{Ca}$ and $\mathrm{Mg}$ ) were significantly affected by Navel orange cultivars, rootstocks and their interaction.}

Egypt. J. Hort. Vol. 41, No. 2 (2014) 
EVALUATION OF SOME NEW NAVEL ORANGE CULTIVARS ...

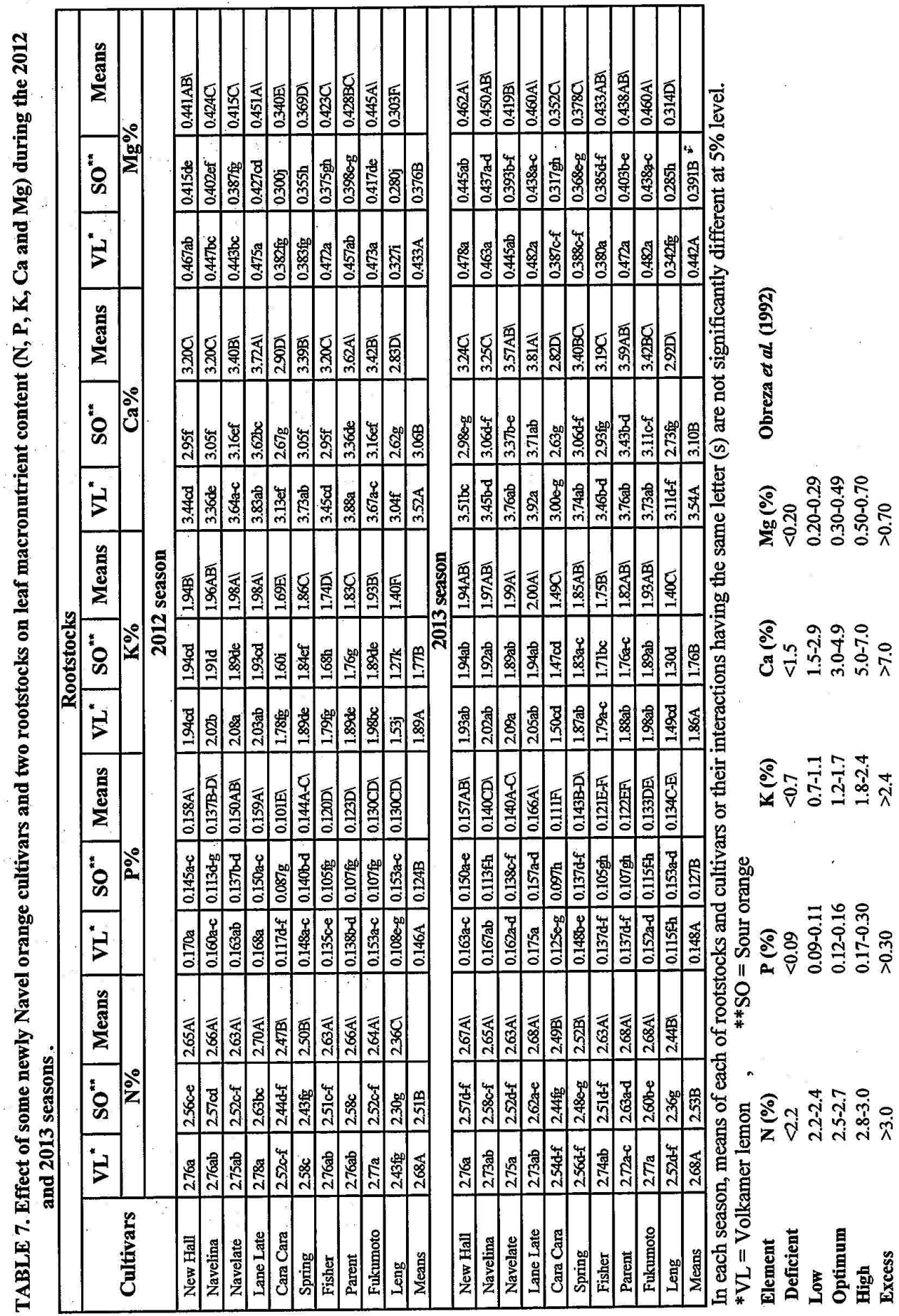

Egypt. J. Hort. Vol. 41, No. 2 (2014) 
Consequently, all Navel orange cultivars gave values in the optimum nitrogen levels except "Leng" especially in the first season. Meanwhile, "Cara Cara" and "Spring" gave significant lower values than other Navel orange cultivar in both seasons. With respect to rootstocks it was observed that, VL gave the significant highest values during the two seasons. Regarding the interaction, the least significant values were obtained by Leng on SO in the two seasons. On the other hand, the significant highest values were obtained when grafting different Navel orange cultivars on VL as compared with SO rootstock except "Cara Cara", "Spring" and "Leng" in both seasons.

Concerning phosphorus content, the significant highest phosphorus values were obtained by "New Hall", "Navelate" and "Lane Late" in the two growing seasons. On the other hand, VL gave the highest values of phosphorus content as compared with SO rootstock. Regarding the interaction, the significant highest values of phosphorus content were obtained when grafting (New Hall and Lane Late) on each rootstocks, (Navelina, Navelate and Fukumoto) on VL and (Leng) on SO in the two seasons. The least significant and suboptimal values where obtained when grafting other cultivars especially on SO rootstock.

In respect to potassium content, the significant highest values of potassium content were obtained by "Navelina", "Navelate" and "Lane Late" in the two seasons. With respect to rootstocks it was observed that, VL rootstock gave the significant highest values of potassium content. Regarding the interaction it was clear that the trend was slightly different from the season to another. In the first season, the significant highest values were obtained from "Navelate" and "Lane Late" on VL while the least significant value was obtained for Leng on SO. In the second season, all Navel orange cultivars gave the significant highest values on each rootstock as compared with "Cara Cara" and "Leng".

Concerning calcium content, the significant highest values were obtained from "Navelate", "Lane Late" and "Parent" cultivars especially in the second season. On the other hand, VL rootstock gave the significant highest values of calcium content. Regarding the interaction it could be observed that the significant highest values were obtained when grafting "Navelate", "Lane Late", "Spring", "Parent" and "Fukumoto" cultivars on VL as compared with SO.

Regarding Mg content, results proved that the New Hall, Lane Late and Fukumoto cultivars gave the highest values of $\mathrm{Mg}$ content especially in the first season. On the other hand, VL gave the highest values of Mg content during the two growing seasons. Regarding the interaction, it is quite evident that in the first season, the significant highest values of $\mathrm{Mg}$ content were obtained when grafting different Navel orange cultivars on VL as compared with SO. On the other hand in the second season, the significant highest values were obtained from New Hall, Navelina, Lane Late and Fukumoto on each rootstocks and Navelate, Fisher and Parent on VL rootstock.

Egypt. J. Hort. Vol. 41, No. 2 (2014) 
General VL rootstock gave the significant highest values of macronutrients content (N, P, K, Ca and $\mathrm{Mg}$ ) as compared with SO rootstock. These results are in harmony with these found by Khankahdani et al. (2006) El-Sayed (2013) and Barakat et al. (2013) who revealed that, VL generally exhibited significantly higher $\mathrm{N}, \mathrm{P}, \mathrm{K}$ and $\mathrm{Mg}$ content in Navel orange leaves compared to SO rootstock in both seasons. On the other hand, these results are in disagreement with those found by Hafez (2006) and Abdolhossein et al. (2012) who noticed that N, P and $\mathrm{K}$ in leaves recorded the highest values with the $\mathrm{SO}$ rootstock seedling.

\section{Effect on leaf micronutrients content}

Results in Table 8 show the effect of different Navel orange cultivars, rootstocks and their interaction on $\mathrm{Fe}, \mathrm{Zn}$ and $\mathrm{Mn}$ content in leaves of Navel orange trees in 2012 and 2013 seasons. Results showed that values of micronutrients ( $\mathrm{Fe}, \mathrm{Zn}$ and $\mathrm{Mn}$ ) were significantly affected by Navel orange cultivars, rootstocks and their interaction.

Regarding iron content the data showed that, the significant highest values were obtained by Lane Late cultivar in both the two seasons followed closely by New Hall, Navelina, Navelate, Spring, Fisher and Fukumoto only in the second season. On the other hand, VL rootstock gave the significant highest values during the two seasons. Regarding the interaction it could be observed that the highest values were obtained by some different combinations during the two seasons, but Lane Late on VL rootstock gave the highest values of iron content in $1^{\text {st }}$ and $2^{\text {nd }}$ seasons.

The highest values of zinc content were obtained by Navelate, Lane Late, Spring and Fisher in the two seasons while other cultivars were resulted in significant lower values except Leng in the second season. Meanwhile, VL rootstock gave the significant highest values during the two seasons. Regarding the interaction, it could be concluded that, all the combinations between different cultivars and VL rootstock gave higher values than the combinations on SO rootstock.

Regarding manganese content, the data showed that, Lane Late cultivar gave the significant highest values of Mn content in both seasons. Also, VL rootstock gave the significant highest values during the two seasons. Regarding the interaction it could be observed that the highest values were obtained by some different combinations during the two seasons whereas, New Hall, Navelina and Lane Late on VL rootstock gave the highest values of Mn content in $1^{\text {st }}$ and $2^{\text {nd }}$ seasons.

From the foregoing results, it could be concluded that, "Cara Cara" "Spring" and "Leng" gave significant lower values of $\mathrm{N}$ content than other Navel orange cultivar. Meanwhile, Navelate and Lane Late gave the highest values of P, K and $\mathrm{Ca}$. On the other hand, Lane Late gave the highest values of $\mathrm{Mg}, \mathrm{Fe}$ and $\mathrm{Mn}$. VL rootstock gave the significant highest values of all macro and micronutrients content. Regarding the interaction between cultivars and rootstocks, generally the highest values of $\mathrm{N}, \mathrm{P}, \mathrm{Ca}, \mathrm{Mg}, \mathrm{Fe}$ and $\mathrm{Mn}$ were obtained when Lane Late budded on VL rootstock 


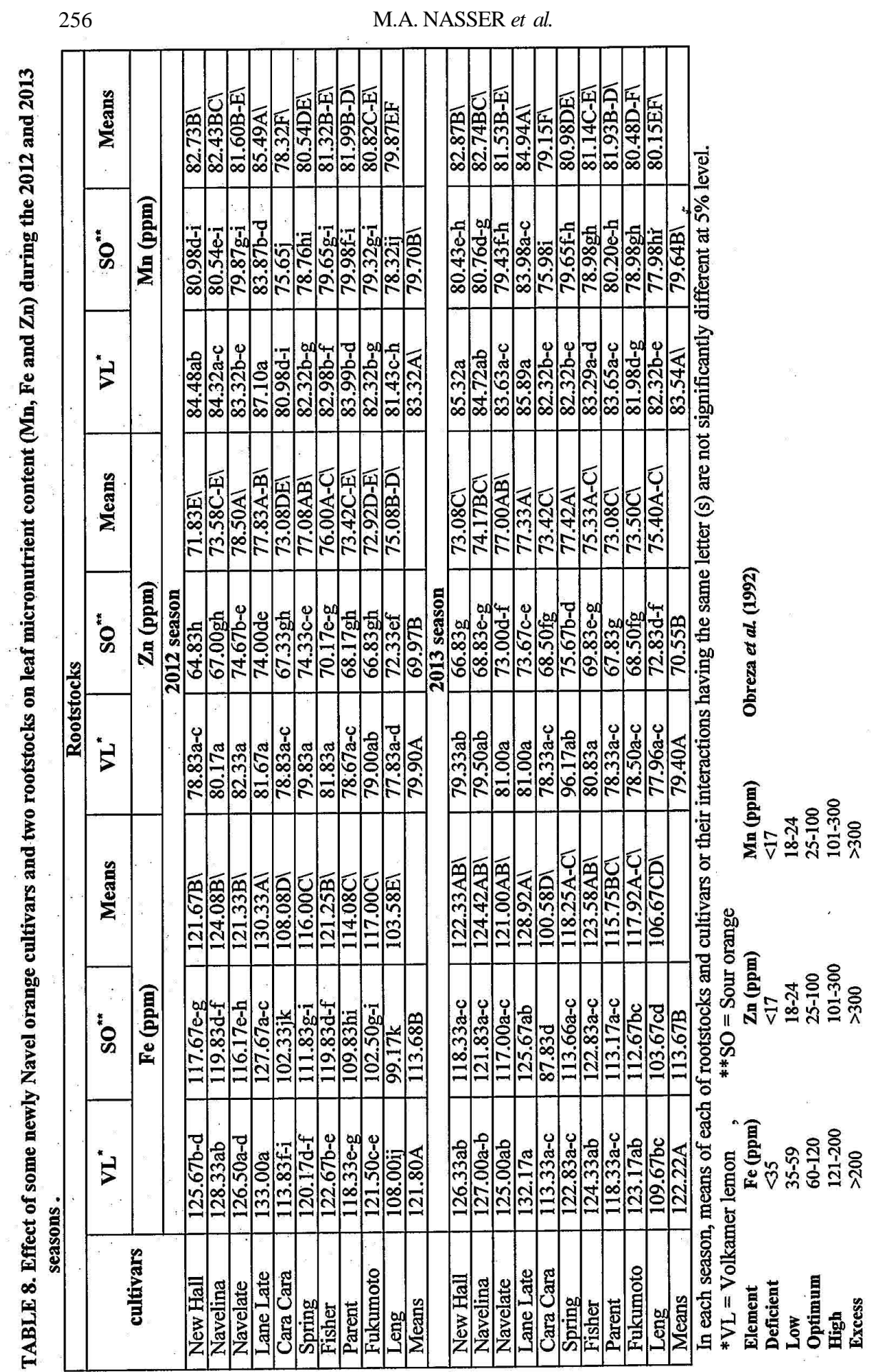

Egypt. J. Hort. Vol. 41, No. 2 (2014) 
The obtained data are in agreement with those reported by El-Sayed and Somaia (2008) reported that, Washington navel orange budded on VL and Rangpure lime rootstocks had significantly higher $\mathrm{N}, \mathrm{K}, \mathrm{Mg}, \mathrm{Fe}$ and $\mathrm{Zn}$ and lower P. Sour orange and troyer citrange rootstocks recorded the highest values of $\mathrm{P}$, moderate values of $\mathrm{Mg}, \mathrm{K}, \mathrm{Fe}, \mathrm{Ca}$ and $\mathrm{Mn}$. Jahromi et al. (2012) and Barakat et al. (2013) who reported that VL rootstock induced higher foliar leaf mineral content as compared with SO rootstock.

\section{Effect on $C / N$ ratio}

Results in Table 9 show the effect of different Navel orange cultivars, rootstocks and their interaction on $\mathrm{C} / \mathrm{N}$ ratio in stems of Navel orange trees in 2012 and 2013seasons. Results showed that values of total carbohydrates, total N and $\mathrm{C} / \mathrm{N}$ ratio were significantly affected by Navel orange cultivars, rootstocks and their interaction.

The significant highest values of total carbohydrate were obtained by New Hall and Lane Late through two seasons. Regarding the rootstocks, SO gave the significant highest values of total carbohydrate during the two seasons. Concerning the interaction, New Hall, Navelate and Lane Late budded on SO gave the significant highest values of total carbohydrate during the two seasons.

While the significant highest values of total nitrogen were obtained by Lane Late during the two seasons whereas, some other cultivars gave the same highest values such: (Navelina) and (New Hall, Fisher, Parent and Leng) in the first and second seasons, respectively. Results showed that values of $\mathrm{N}$ were significantly affected by rootstocks in the first season only and VL. rootstock gave the significant highest value. Regarding the interaction it was clear that the trend was slightly different from one season to another. In the first season, the significant highest values of $\mathrm{N}$ were obtained when grafting New Hall, Navelina, Lane Late and Fisher on VL and other combinations gave more or less similar lower values. On the other hand in the second season, the significant highest values were obtained from New Hall, Lane Late, Fisher, Parent and Leng on each rootstocks and Navelina, Cara Cara on VL rootstock. Meanwhile, Navelate and Fukumoto cultivars gave the least significant values of $\mathrm{N}$ content on each rootstock.

The significant highest values of $\mathrm{C} / \mathrm{N}$ ratio were obtained by New Hall, Navelate, Spring, and Fukumoto in two seasons. Meanwhile, SO rootstock gave the significant highest values of $\mathrm{C} / \mathrm{N}$ ratio during the two seasons. Regarding the interaction, it could be concluded that, all the combinations between different cultivars on SO rootstock gave higher values than the combinations on VL rootstock.

From the foregoing results, it could be concluded that, VL gave lower values of total carbohydrates consequently gave lower values of $\mathrm{C} / \mathrm{N}$ ratio than $\mathrm{SO}$ rootstock. In the same time, all Navel orange cultivars budded on VL rootstock gave lower $\mathrm{C} / \mathrm{N}$ ratio than budded on $\mathrm{SO}$ rootstock. 
M.A. NASSER et al.

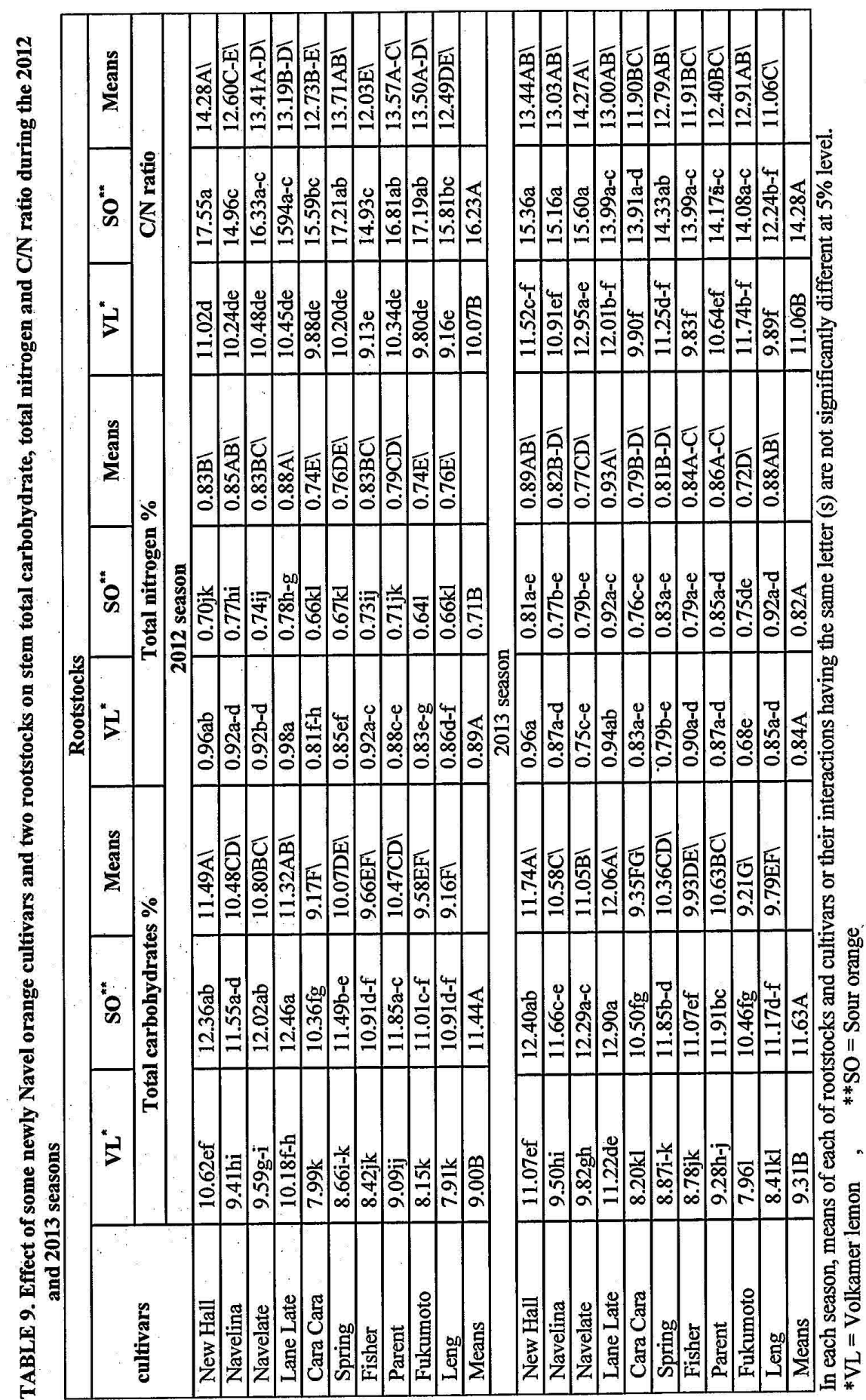

Egypt. J. Hort. Vol. 41, No. 2 (2014) 
Generally, combinations between different cultivars on VL rootstock gave lower values of $\mathrm{C} / \mathrm{N}$ ratio than $\mathrm{SO}$ rootstock but in the same time gave highest values of fruit set and yield may be due to the increase of scions vigor budded on VL rootstock resulted from increase the nutrients absorption efficiency from soil which reflected in the canopy growth, leaf mineral content and yield. So, it was expected that, after few years Navel orange cultivars budded on VL rootstock may be suffer from alternate bearing.

Regarding data for effect of rootstocks on $\mathrm{C} / \mathrm{N}$ ratio, similar results were found by Zayan et al. (2004) who found that $\mathrm{C} / \mathrm{N}$ ratio of Valancia orange trees budded on VL and Rangpur lime recorded the significant lowest values of $\mathrm{C} / \mathrm{N}$ ratio. Whereas trees budded on Troyer citrange recorded highest value of $\mathrm{C} / \mathrm{N}$ ratio. While trees budded on $\mathrm{SO}$ rootstock recorded intermediate values of $\mathrm{C} / \mathrm{N}$ ratio.

\section{Conclusion}

From the aforementioned results, it could be concluded that, VL rootstock was more effective in improving yield and leaf mineral content of all cultivars but with low fruit quality than SO rootstock. Regarding cultivars, New Hall gave the highest values of fruit weight and yield/tree followed by Navelina and Lane Late but New Hall especially on VL gave large fruit size which not accepted in export and local market. So, it could be recommended by budded Navelina and Lane Late cultivars on SO rootstock for suitable yield with high fruit quality.

\section{References}

A.O.A.C. (1995) "Official Method and Analysis", Association of The Official Analytical Chemists. $16^{\text {th }}$ ed., Washington DC., USA.

Abdolhossein, A.J. Hasanzada, H. and Farahi, M.H. (2012) Effect of rootstocks type and scion cultivar on citrus leaf total nitrogen. World Appl. Sci. J., 19 (1),140-143

Agricultural Statistics Institute (2013) Agricultural Statistics Institute, summer and Nile crops, Egypt, 2(1), 298-327.

Barakat, M.R., Yehia, T.A. and Sayed, B.M. (2012) Response of Newhall Naval orange to bio-organic fertilization under newly reclaimed area conditions I: Vegetative growth and nutritional status. J. Hort. Sci. \& Ornamental Plants, 4 (1), 18-25.

Barakat, M.R., Mohsen, A.T. Abdel-El-Rahman, A.M. and Hemeda, S.H. (2013) Nutritional status and yield efficiency of Navel and Valencia orange trees as affected by used rootstocks. J. Hort. Sci. \& Ornamental Plants, 5 (2), 137-144.

Black, C.A., Evans, D.D. White, J.L. Ensminger, L.E. and Clark, F.E. (1965) "Method of Soil Analysis", Part2. Amer. Soc. Agron. Inc., Madison, Wisconsin. USA, pp.112-201.

Castle, W.S. (2010) A career perspective on citrus rootstocks, their development, and commercialization. HortScience, 45 (1), 11-15. 
Cottenie, A., Verloo, M. Kiekens, L. Velgh, G. and Camerlynk, R. (1982) Chemical analysis of plants and soils state Univ. Ghent, Belgium, 63, 44-45.

Dubois, M., Gilles, K.A. Hamilton, J.K. Rebers, P.A. and Smith, F. (1956) Colorimetric method for determination of sugars and related substances. Annal. Chem., 26, 350-356.

El- Sayed, M.O. (2013) Mutual effect between three orange Cvs. and sour orange and volkameriana rootstocks in newly reclaimed lands. Arab Univ. J. Agric. Sci., Ain Shams Univ., Cairo, 21 (2), 217-231.

El-Sayed, A. Somaia (2008) Nutritional status of different parts of tree and fruit of Washington Navel orange as affected by five different rootstocks. Hort. Dept., Sakha Agric. Res. St., Kafr El-Sheikh, Egypt. Minufiya J. Agric. Res., 33 (3), 797-809.

FAO Corporate document Repository, Virus like diseases of citrus in the near east. http://www.fao.org/docrep/u5000e/U5000E0d.htm

Ferguson L., Elliot, E. and Cardwell, G. (2014) "Citrus Production Manual", Univ. of Calif. Agric. and Natural Resources p.69.

Hafez, O.M. (2006) Evaluation of growth characteristics of some citrus rootstocks protein finger print technique. Amer. Eurasian J. Agric. and Environ. Sci., 1 (3), 243-248

Harding, P.L., Winston, J.R. and Fisher, D.F. (1940) Seasonal changes in Florida

Hifny, H.A., Abd Elrazik, A.M., Abdrabboh, G.A. and Sultan, M.Z. (2012) Effect of some citrus rootstocks on fruit quality and storability of Washington Navel orange under cold storage conditions. J. Agric. \& Environ. Sci., 12 (10), 1266-1273.

Hudson, T.H., Kaster, D.E. and Davies, F.T. (1990) "Plant Propagation Principles and Practices", $5^{\text {th }}$ ed. Prentice-Hall International, INC. p 538.

Ibrahim, A.M., Saad Allah, M.H. El-Wakeel, H. and Abou Rawash, M. (2004) Effect of four citrus rootstocks on growth, flowering, yield and fruit quality of Valencia orange cultivar. Annal. Agric. Sci., Moshtohor, Egypt, 42 (4), 1983-1998.

Jackson, G. (1958) Soil Chemical Analysis, Pretice Hall of Indian Private limited, New Delhi. (c.f. Abd El-Rahman, 1994).

Jackson, M.L. (1973) Soil Chemical Analysis, Prentice-Hall of India Private Limited, New Delhi.

Jahromi, A.A., Hasanzadaand, H. and Farahi, M.H. (2012) Effect of rootstock type and scion cultivar on citrus leaf total nitrogen. World Appl. Sci. J., 19 (1), 140-143.

Khankahdani, H. H., Hasanpour, A. and Aboutalebi, A. (2006) Effect of different rootstocks on vegetative growth, dry matter and mineral concentration of Mexican lime (Citrus aurantifolia Swingle). Seed and plant. 22:2, pel 55- pel 66, en 12.15 ref. Iran 
Obreza, T.A., Alva, A.K., Hanlon, E.A. and Rouse, R.E. (1992) Citrus grove leaf tissue and soil testing: sampling, analysis, and interpretation. This document is SL-115, a fact sheet of the Soil and Water Sci. Dept., Florida Coop. Exten. Service, Inst. of Food and Agric. Sci., Univ. of Florida. First published: June 1992, revised: October 1999.

Shafieizargar, A., Awang, Y. Juraimi, A. and Othman, R. (2012) Yield and fruit quality of 'Queen' orange [Citrus sinensis (L) Osb.] grafted on different rootstocks in Iran, AJCS, 6 (5), 777-783.

Snedecor, G.M. and Cochran, W.G. (1980) "Statistical Methods", $6^{\text {th }}$ ed., lowa State Univ. Press, Ames. lowa, USA.

UPECH (2013) Quarantine, Union of Producers \& Exporters of Horticultural Crops.

Wilde, S.A., Corey, R.B., Layer, L.J. and Voigt, G.K. (1979) "Soil and Plant Analysis For Tree Culture", Published by Oxford IBH publishing Co,"New Delhi, India. (CAB Abst.).

Zayan, M.A., Zeerban, S.M., Ayaad, H.M., Dawood, S.A. and Ennab, H.A. (2004) Evaluation study on Washington Navel orange cultivar budded on five rootstocks. $J$. Agric. Res. Tanta Univ., 30 (2), 400-420.

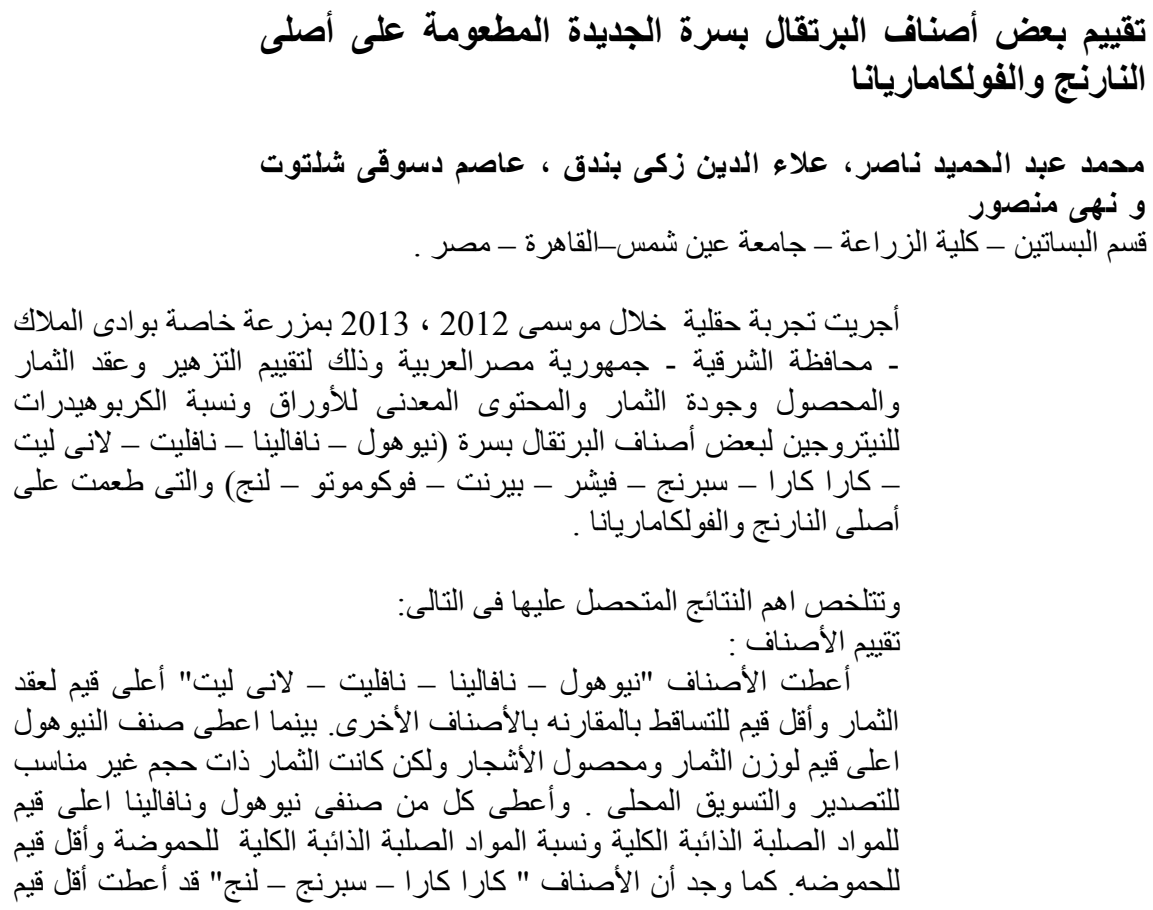




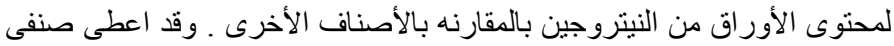

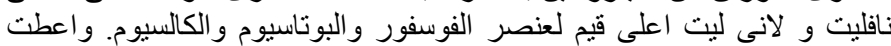

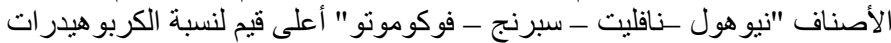
للنيتروجين.

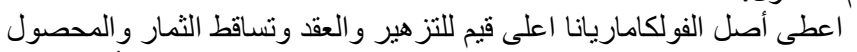

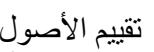

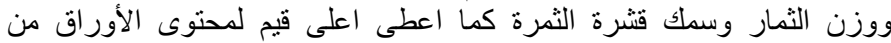

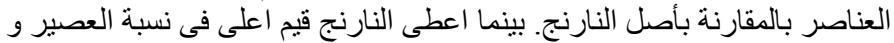

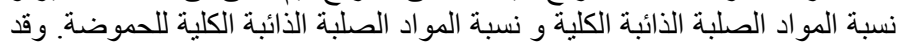

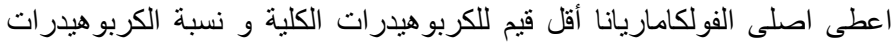

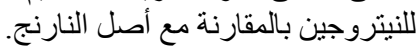

على الرغم من أن اصل الفولكاماريانا اعطى محصو لاًا اعلى من اصل اصل النارنج

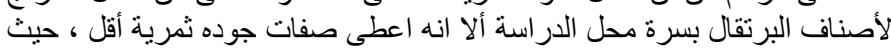

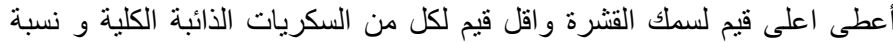
السكريات الذائبة الكلية للحموضه.

$$
\text { التأثثر المتبادل بين الأصل و الطعم: }
$$

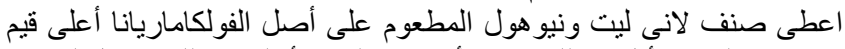

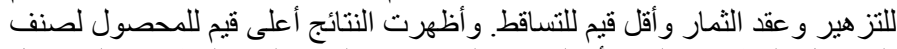

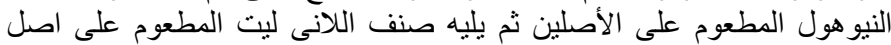

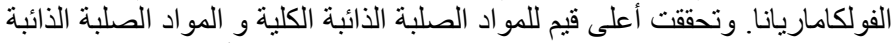

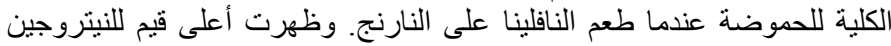

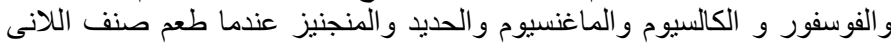
ليت على اصل الفولكاماريانا.

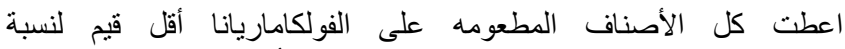
الكربو هيدر ات للنيتروجين بالمقارنة بتلك المطعومة على أصل النارئن

مما سبق يمكن التوصية بأنه يفضل زراعة صنفى النافالينا واللانى ليت

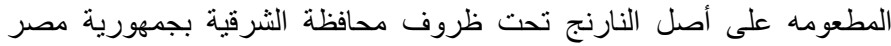

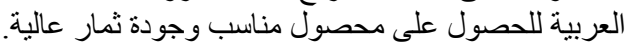

